\title{
Engine Torque Control of SI Engine using Linear Quadratic Integral Tracking (LQIT) Optimal Control
}

\author{
Aris Triwiyatno ${ }^{1}$, Mohammad $\mathrm{Nuh}^{2}$, Ari Santoso ${ }^{2}$, and I Nyoman Sutantra ${ }^{3}$
}

\begin{abstract}
Due to the needs of improving fuel economy and reducing emissions, it is increasingly important to achieve control over robustness behavior and meet performance objectives over the life of the vehicle. This requires the development of high performance and optimal power train controllers. The performance objectives are often conflicting, or at least interrelated. One way to potentially meet these performance requirements is to introduce a method of controlling engine torque of Spark Ignition (SI) engine using Linear Quadratic Integral Tracking (LQIT) optimal control. The goal is to develop simple algorithms which can control engine torque well, thus providing fuel control more efficient and simultaneously improving engine performance due to the needs of the driver based on throttle opening information. In this case, spark ignition engine with automatic transmission simulation model is used to meet a good performance under this controller design.
\end{abstract}

Keywords —engine torque, LQIT optimal control, SI engine

Abstrak-Berkenaan dengan adanya regulasi dan kebijakan pemerintah terkait dengan ketentuan teknologi otomotif yang hemat energi dan ramah lingkungan, maka pengembangan teknologi kontrol untuk memperbaiki waktu transien pada mesin kendaraan dengan menjaga kinerjanya tetap baik, menjadi permasalahan sangat penting. Untuk dua pekerjaan ini diperlukan pengembangan teknologi kontroler dengan kinerja tinggi dan optimal. Hal ini dikarenakan upaya untuk melakukan penghematan energi/bahan bakar dan menjaga kinerja mesin otomotif tetap baik merupakan upaya yang saling bertentangan atau paling tidak saling melemahkan. Salah satu metode kontrol yang secara potensial bisa dimanfaatkan untuk permasalahan ini adalah dengan melakukan pengaturan engine torque pada Spark Ignition (SI) engine dengan menggunakan Linear Quadratic Integral Tracking (LQIT) optimal control. Tujuan dari penelitian ini adalah membuat suatu algoritma kontrol torsi mesin sederhana yang dapat digunakan untuk penghematan penggunaan bahan bakar dan juga sekaligus menjaga kinerja dari mesin sesuai dengan informasi bukaan pedal gas yang diberikan pengemudi. Pada kasus penelitian ini akan digunakan model simulasi spark ignition engine dengan automatic transmission untuk menghasilkan pembangkitan torsi sesuai dengan metode kontrol tersebut.

Kata Kunci-torsi mesin, kontrol optimal LQIT, SI mesin

\section{INTRODUCTION}

$\mathrm{O}$ ver the last three decades there has been a dramatic evolution in spark ignition engine control systems, largely driven by government regulations and policies aimed at improving fuel economy and reducing emissions. It is increasingly important to achieve control over robustness behavior and meet performance objectives over the life of the vehicle. This requires the development of high performance and optimal power train controllers. The performance objectives are often conflicting, or at least interrelated. Due to this reasons controlling of automotive engines is needed.

Control of automotive engines focuses on a variety of problems, including control of idle speed, spark timing, air-fuel ratio, and engine torque. Various studies have been done to these efforts, some of which focus on controlling the engine speed and manifold pressure [1-3].

Aris Triwiyatno is with Department of Electrical Engineering, FT, Universitas Diponegoro, Semarang, 50275, Indonesia. E-mail: aristriwiyatno@yahoo.com.

Mohammad Nuh and Ari Santoso are with Department of Electrical Engineering, FTI, Institut Teknologi Sepuluh Nopember, Surabaya, 60111 , Indonesia.

I Nyoman Sutantra is with Department of Mechanical Engineering, FTI, Institut Teknologi Sepuluh Nopember, Surabaya, 60111, Indonesia.
The problem appeared since controlling the engine speed and manifold pressure has not been able to provide solutions to the needs of large instantaneous changes of engine torque. Some studies in this case have been done using intelligent control like fuzzy control and its families [4-5]. But those approaches have not been able to provide a simple control algorithm. Since spark ignition engine needs a fast control feeding, they were not effective. Another approach that proved more effective is by controlling engine torque [6-8], and by using conventional optimal control [8-9]. By controlling engine torque automatically increases vehicle performance, improving fuel economy and reducing emissions. This happens because the maximum engine torque can be achieved only by doing perfect combustion of fuel in the combustion cylinders, meaning to maintain perfect combustion of fuel usage to be effective and efficient [8].

This paper focuses in particular on engine torque control. The goal is to develop algorithms which can control engine torque well, thus providing fuel control more efficient and simultaneously improving engine performance due to the needs of the driver based on throttle opening information. One way to potentially meet these performance requirements is to introduce a method of controlling engine torque using Linear 
Quadratic Integral Tracking (LQIT) optimal control. Due to the lack information of state behavior that needed by the controller, state observer is added to estimate state signal from the system input-output. By using this method, the throttle opening commanded by the driver will be corrected by throttle correction signal that guarantees engine torque output will follow the desired engine torque input. In this case, spark ignition engine with automatic transmission is used to meet a good performance under this controller design.

\section{METHOD}

\section{A. Spark Ignition Engine Modeling}

In this research, we use spark ignition engine model as described in [10]. The model is Ford SI-engine model.

The rate of air into the intake manifold can be expressed as the product of two functions; i.e. an empirical function of the throttle plate angle and a function of the atmospheric and manifold pressures, as shown in Equation 1.

$$
\dot{m}_{a i} \quad=f_{1}(\theta) f_{2}\left(P_{m}\right)
$$

where,

$\dot{m}_{a i} \quad=$ mass flow rate into manifold $(\mathrm{g} / \mathrm{s})$, with

$f 1(\theta)=2.821-0.05231 \theta+0.10299 \theta^{2}-0.00063 \theta^{3}$

$\theta \quad=$ throttle angle $(\mathrm{deg})$

$$
f_{2}(P m)= \begin{cases}1, & P_{m} \leq \frac{P_{a m b}}{2} \\ \frac{2}{P_{a m b}} \sqrt{P_{m} P_{a m b}-P_{m}^{2}}, & \frac{P_{a m b}}{2} \leq P_{m} \leq P_{a m b} \\ -\frac{2}{P_{m}} \sqrt{P_{m} P_{a m b}-P_{m}^{2}}, & P_{a m b} \leq P_{m} \leq 2 P_{a m b} \\ -1, & 2 P_{m} \geq 2 P_{a m b}\end{cases}
$$

$P_{m} \quad=$ manifold pressure $($ bar $)$

$P_{\text {amb }}=$ ambient (atmospheric) pressure (bar), 1 bar

The intake manifold can be modeled as a differential equation for the manifold pressure, as shown in Equation 2.

$$
\begin{aligned}
\dot{P}_{m} & =\frac{R T}{V_{m}}\left(\dot{m}_{a i}-\dot{m}_{a o}\right) \\
& =0.41328\left(\dot{m}_{a i}-\dot{m}_{a o}\right)
\end{aligned}
$$

where,

$R \quad=$ specific gas constant

$T \quad=$ temperature $\left({ }^{\circ} \mathrm{K}\right)$

$V_{m} \quad=$ manifold volume $\left(\mathrm{m}^{3}\right)$

$\dot{m}_{a o} \quad=$ mass flow rate of air out of the manifold $(\mathrm{g} / \mathrm{s})$

$\dot{P}_{m} \quad=$ rate of change of manifold pressure (bar/s), with $P_{0}=0.543 \mathrm{bar}$

The mass flow rate of air that the model pumps into the cylinders from the manifold is described in Equation 3 by an empirically derived equation.

$$
\begin{aligned}
\dot{m}_{a o}= & -0.366+0.08979 N P_{m}-0.0337 N P_{m}^{2} \\
& +0.0001 N^{2} P_{m}
\end{aligned}
$$

where,

$\dot{m}_{a o} \quad=$ mass flow rate of air out of the manifold $(\mathrm{g} / \mathrm{s})$

$N \quad=$ engine speed $(\mathrm{rad} / \mathrm{s})$

$P_{m} \quad=$ manifold pressure (bar)
The torque developed by the engine is described as in Equation 4.

$$
\begin{aligned}
T_{\mathrm{e}}= & -181.3+379.36 m_{\alpha}+21.91(A / F) \\
& -0.85(A / F)^{2}+0.26 \sigma-0.0028 \sigma^{2} \\
& +0.027 N-0.000107 N^{2}+0.00048 N \sigma \\
& +2.55 \sigma m_{\alpha}-0.05 \sigma^{2} m_{\alpha}
\end{aligned}
$$

where,

$m_{a} \quad=$ mass of air in cylinder for combustion $(\mathrm{g})$

$A / F \quad=$ air to fuel ratio

$\sigma=$ spark advance (degrees before top-deadcenter/TDC)

$T_{e} \quad=$ torque produced by the engine $(\mathrm{Nm})$

Fuel consumption can be estimated with air-to-fuel ratio estimation $(A / F)$ and mass of air in cylinder for combustion $\left(m_{a} \approx m_{a o}\right)$ in Equation 3 ; as shown in Equation 5.

Fuel $=\frac{m_{a}}{A / F}$

where,

Fuel = fuel consumption (g)

$m_{a} \quad=$ mass of air in cylinder for combustion $(\mathrm{g})$

$A / F \quad=$ air to fuel ratio

The engine torque less the impeller torque results in engine acceleration; as in Equation 6.

$I_{e i} \dot{N} \quad=T_{e}-T_{L}$

where,

$I_{e i} \quad=$ engine rotational + impeller moment of inertia $\left(\mathrm{kg}-\mathrm{m}^{2}\right)=0.14 \mathrm{~kg}-\mathrm{m}^{2}$

$\dot{N} \quad=$ engine acceleration $\left(\mathrm{rad} / \mathrm{s}^{2}\right)$, with initial engine speed $N_{0}=209.48 \mathrm{rad} / \mathrm{s}$

$T_{e} \quad=$ torque produced by the engine $(\mathrm{Nm})$

$T_{L} \quad=$ load torque $(\mathrm{Nm})$

Load torque $\left(T_{L}\right)$ generally produced by vehicle dynamics. The vehicle model with 4-step automatic gear transmission that used in this engine model application is derived based on state-flow model as in [10].

\section{B. Engine Torque Management Strategy}

Basically, the engine torque management strategy use throttle opening control function, Air to Fuel Ratio (AFR), and ignition timing simultaneously to produce desired engine torque [8]. In practical reality, desired engine torque does not exist, because the input given by the driver on the system is the position of the accelerator pedal (pedal position). For that reason, the engine torque control strategy known as the mapping between the position of throttle opening (pedal position) and engine speed with engine torque command [6]. Figure 1 shows the mapping for economical vehicle feel. Desired engine torque as output reference in engine torque control system is determined using this mapping.

In this research, engine torque control regulation conducted only by controlling throttle plate angle. As assumed in introduction that maximum engine torque can be achieved only by doing perfect combustion of fuel in the combustion cylinders, we used AFR and ignition time left on the standard setting that ideally yield perfect combustion, i.e. at 14.7 AFR and the spark advance to 15 degree Before-Time-Dead-Center (BTDC), respectively [11]. 


\section{Linear Quadratic Integral Tracking (LQIT) Problem Optimal Control Design}

The Linear Quadratic Regulator (LQR) controller [11] is designed to drive the states to zero. This is a limitation since most control systems are tracking systems, where the output is forced to achieve a desired value.

Consider the system:

$\dot{x}=A x+B u$

and the output equation:

$y=C x$

where $y$ is the output of the system and $C$ is a matrix. Assume that the output vector $y$ has the same dimension as the input vector $u$. In the steady state, we assume that for an output reference $r$ there exists a combination of state $\bar{x}$ and input $\bar{u}$ that makes $y=r$. This implies that $A$ must be invertible (no zero eigen-values) and that the inverse of $C A^{-1} B$ must exist.

$\dot{\bar{x}}=A \bar{x}+B \bar{u}=0 \rightarrow \bar{x}=-A^{-1} B \bar{u}$

Substituting in (8) yields:

$\bar{y}=-C A^{-1} B \bar{u}=r \rightarrow \bar{u}=-\left[C A^{-1} B\right]^{-1} r$

1. Tracking Via Coordinate Translation

An intuitive approach to make the output $y$ follow a reference $r$ is to replace the state equation in LQR with a state equation.

Define $\tilde{x}=x-\bar{x}$ and , $\tilde{u}=u-\bar{u}$ then the errors satisfy: $\dot{\tilde{x}}=A \tilde{x}+B \tilde{x}$

A suitable performance index would be:

$J=\int_{0}^{\infty} \tilde{x}^{T} Q \tilde{x}+\tilde{u}^{T} R \tilde{u}, Q \geq 0, R \geq 0$

If the pair $(A, B)$ is stabilizable and $\left(A, Q^{I / 2}\right)$ is observable, the optimal feedback law is:

$\tilde{u}(t)=-K \tilde{x}(t) \rightarrow u(t)=\bar{u}(t)-K(x(t)-\bar{x}(t))$

where $K=R^{-1} B^{T} S$ and $S$ is the solution to the Algebra

Riccati Equation (ARE):

$0=A^{T} S+S A-S B R^{-1} B^{T} S+Q$

Replacing the values for $\bar{u}$ and $\bar{x}$ in (13):

$$
\begin{aligned}
u(t) & =-K x(t)+K A^{-1}\left(C A^{-1} B\right)^{-1} r-\left(C A^{-1} B\right)^{-1} r \\
& =-K x(t)+\left[K A^{-1} B-I\right]\left(C A^{-1} B\right)^{-1} r \\
& =-K x(t)+F r
\end{aligned}
$$

where $F$ is given by:

$$
F=\left[K A^{-1} B-I\right]\left(C A^{-1} B\right)^{-1}
$$

2. Tracking Optimal Control with Integral Action Integral action is used in classical control to eliminate steady state errors when tracking constant signals. Integral control can be generated in a Linear Quadratic (LQ) problem optimal control setting by considering the integral of the output error as an extra set of state variables.

The integral of tracking error is generated by the following differential equation:

$$
\begin{aligned}
\dot{w} & =r(t)-y(t) \\
& =r(t)-C x(t)
\end{aligned}
$$

where,

$r(t)=$ reference signal

$y(t)=$ output signal

$C=$ output matrice of state equation

$\dot{w}=$ error between output and reference

Define an augmented state error:

$$
\hat{x}=\left[\begin{array}{l}
\tilde{x} \\
w
\end{array}\right]
$$

Then the augmented error state equation is:

$\dot{\hat{x}}(t)=\underbrace{\left[\begin{array}{cc}A & 0 \\ -C & 0\end{array}\right]}_{\hat{A}} \hat{x}+\underbrace{\left[\begin{array}{c}B \\ 0\end{array}\right] \tilde{u}}_{\hat{B}}$

A suitable performance index would be:

$J=\int_{0}^{\infty} \hat{x}^{T} Q \hat{x}+\tilde{u}^{T} R \tilde{u}, Q \geq 0, R \geq 0$

The optimal control law is as following:

$\tilde{u}=-K \hat{x}$

where,

$K=R^{-1} \hat{B}^{T} S=\left[\begin{array}{ll}K_{x} & K_{w}\end{array}\right]$

$S$ is the solution to the ARE:

$0=\hat{A}^{T} S+S \hat{A}-S \hat{B} R^{-1} \hat{B}^{T} S+Q$

Using the definitions for $\hat{x}$ and $\tilde{u}$, we have:

$u=-K_{x} \tilde{x}-K_{w} w+\bar{u}$

but $\tilde{x}=x-\bar{x}$, therefore:

$u=-K_{x}(x-\bar{x})-K_{w} w+\bar{u}$

We have seen before that $\bar{u}=-\left(C A^{-1} B\right)^{-1} r$ and $x=A^{-1} B\left(C A^{-1} B\right)^{-1} r$, the control law is then:

$\mathrm{u}=-\mathrm{K}_{\mathrm{x}} \mathrm{x}-\mathrm{K}_{\mathrm{w}} \mathrm{w}+\mathrm{K}_{\mathrm{r}} \mathrm{r}$

where,

$K_{r}=\left[K_{x} A^{-1} B-I\right]\left(C A^{-1} B\right)^{-1}$

A block diagram of this Linear Quadratic Integral Tracking (LQIT) controller is depicted in Figure 2.

3. Output Error Weighting

Note that if the performance index has the form:

$J=\frac{1}{2} \int_{0}^{\infty}\left\{(y-r)^{T} Q_{y}(y-r)+w^{T} Q_{w} w+\bar{u}^{T} R \bar{u}\right\} d t$

it can be reduced to the state error weighting form:

$J=\frac{1}{2} \int_{0}^{\infty}\left\{\hat{x}^{T} Q \hat{x}+\bar{u}^{T} R \bar{u}\right\} d t$

by using

$Q=\left[\begin{array}{cc}C^{T} Q_{y} C & 0 \\ 0 & Q_{w}\end{array}\right]$

4. State Observer

As shown in (26), to produce control action signals, LQIT optimal controller needs state information signal from the plant. In reality, not all state information is measured. State observer is a method to estimate state signals from given plant input-output. 
Introduce a Linear-Time-Invariant (LTI) plant with state equations as,

$$
\begin{aligned}
& \dot{x}(t)=A x(t)+B u(t) \\
& y(t)=C x(t)
\end{aligned}
$$

State estimation of this LTI plant can be shown as:

$$
\dot{\hat{x}}=A \hat{x}+B u+K_{e}(y-C \hat{x})
$$

where

$\hat{x}=$ state estimation

$K_{e}=$ estimation gain

$y=$ plant output

$u=$ plant input

and $K_{e}$ can be easily calculated with pole placement method on eigen-values of $\left[A-B K_{x}\right]$ matrix.

\section{RESULTS AND DISCUSSION}

Simulations were performed with Matlab Simulink as shown in Figure 3 and Figure 4 (see Appendix A for more model information). The simulation results without the controller are shown in Figure 5 and Figure 6. Figure 5 shows that there is a large enough difference between actual engine torque and desired engine torque (as shown with large integral torque absolute error in simulation result, i.e. 4073) when the throttle valve opening using the driver given is as shown in Figure 6. Figure 7 and Figure 8 shows the results after being given a LQIT optimal controller using torque engine mapping for
Economical Vehicle Feel in Figure 1. Figure 7 shows that the actual engine torque will be closer to the desired engine torque (as shown with smaller integral torque absolute error in simulation result, i.e. 268.9) when the throttle valve opening uses the output of the LQIT optimal controller is as shown in Figure 8.

Other results of simulation show that integral torque absolute error of operation without a controller is 4073 and by the application of LQIT optimal controller is 268.9 or there is an improvement of $93.40 \%$. Under the simulation inputs, fuel consumption estimation of operations without the controller is 3896 grams and by the application of LQIT optimal controller is 3397 grams or there is a decrement of $12.81 \%$.

\section{CONCLUSION}

From this research, it can be concluded that the use of linear quadratic integral tracking optimal control system applications will be very beneficial to overcome control problems with performance index contradictory as torque settings on spark ignition engines. In future works, it needs further investigations to the control rule according to the manufacturer's standards and drive the action that is given not only opening the throttle valve, but also includes the arrangement of air to fuel ratio and ignition time. Thus the optimal control rules have the discretion to reduce the use excess fuel to get the engine torque as close as possible to the desired engine torque.

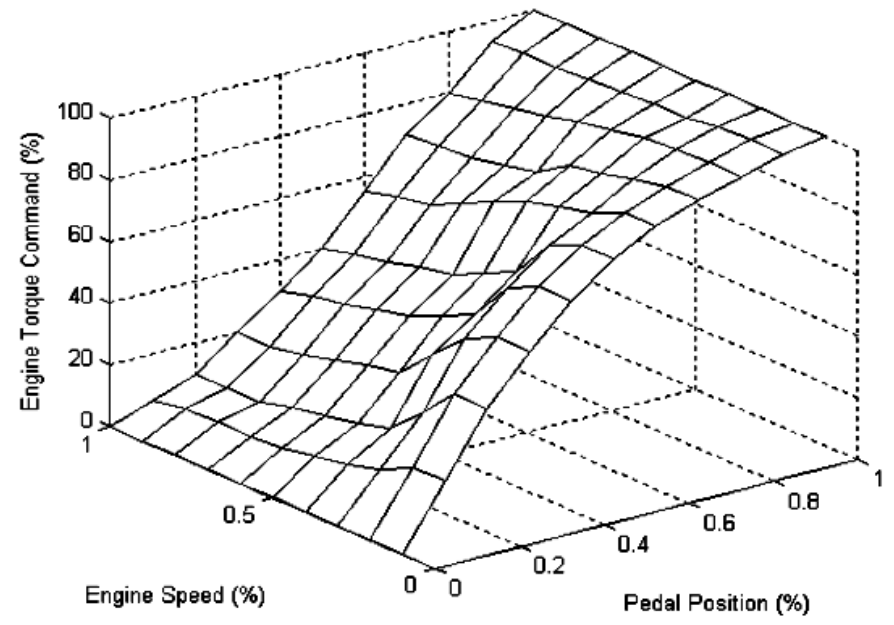

Figure 1. Mapping pedal position and engine speed with engine torque command for economical vehicle feel [6]

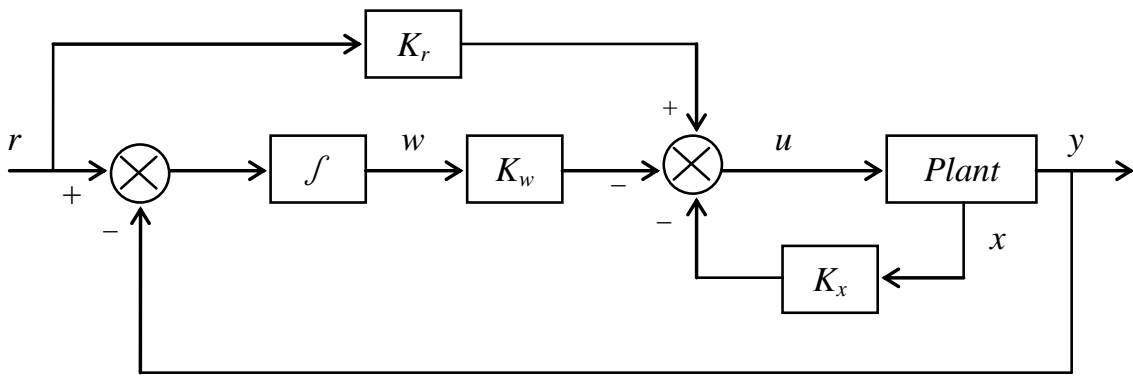

Figure 2. Block diagram of the Linear Quadratic Integral Tracking (LQIT) optimal controller 

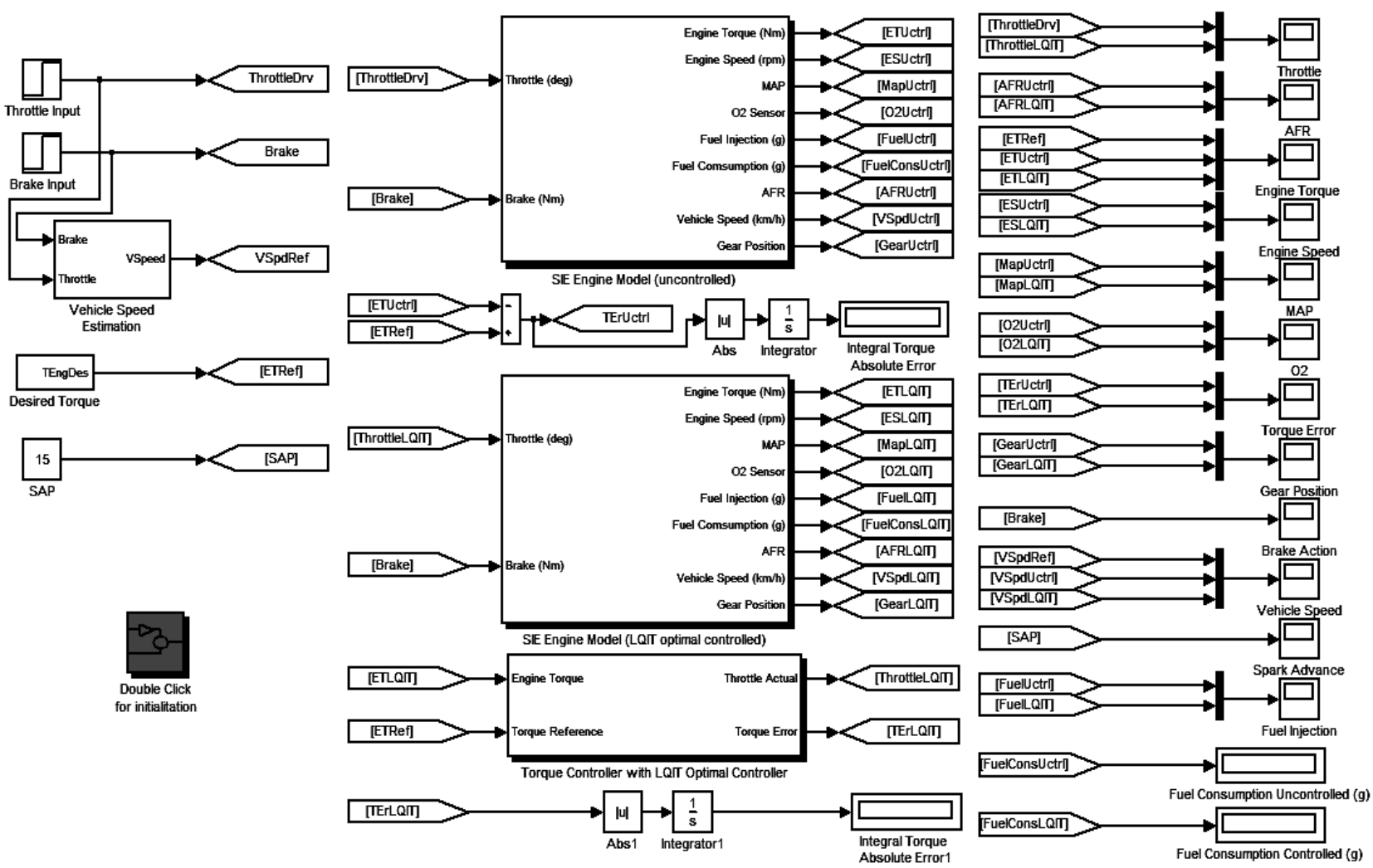

Figure 3. Simulation main model using Matlab simulink toolbox

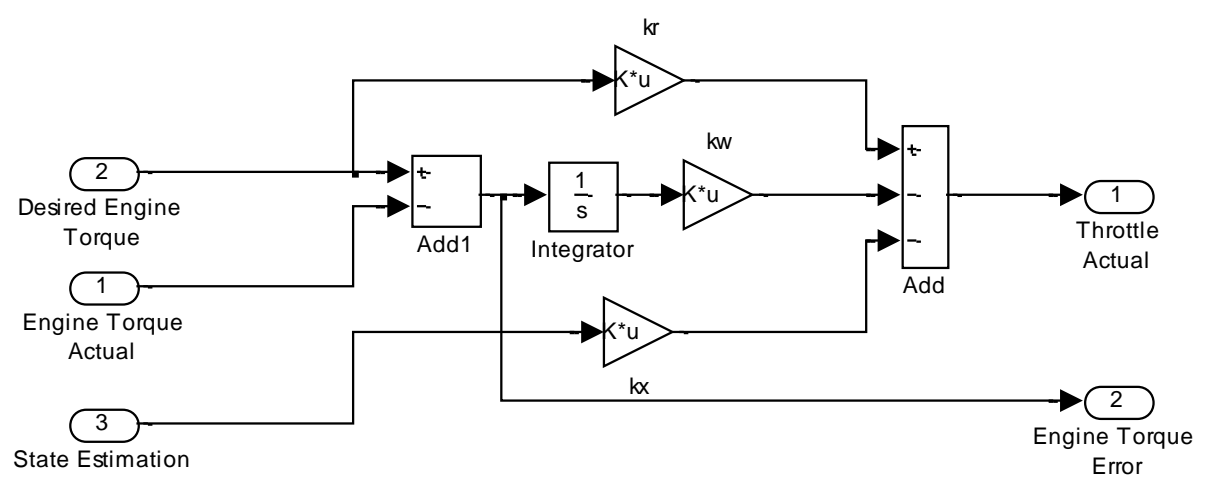

Figure 4. LQIT optimal control simulation sub-model using Matlab Simulink Toolbox

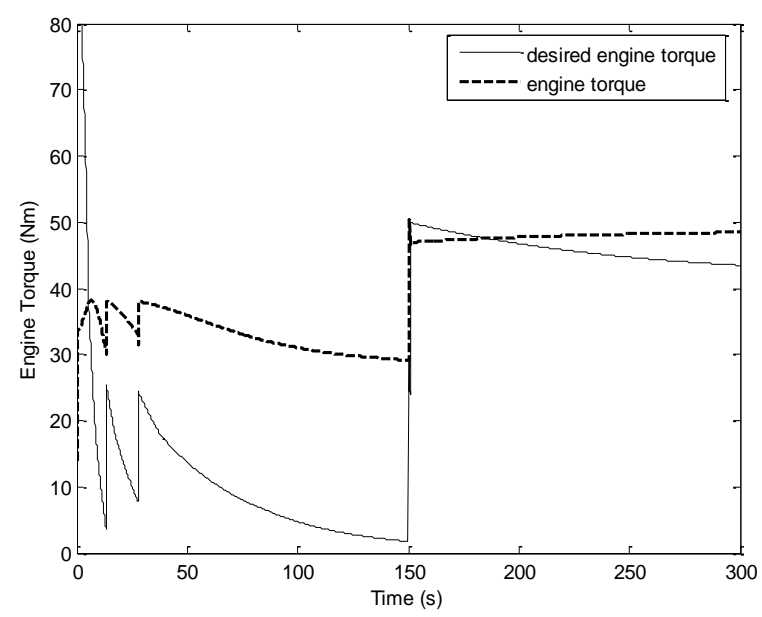

Figure 5. Engine operating without a controller: desired engine torque (reference) vs. engine torque (actual engine torque)

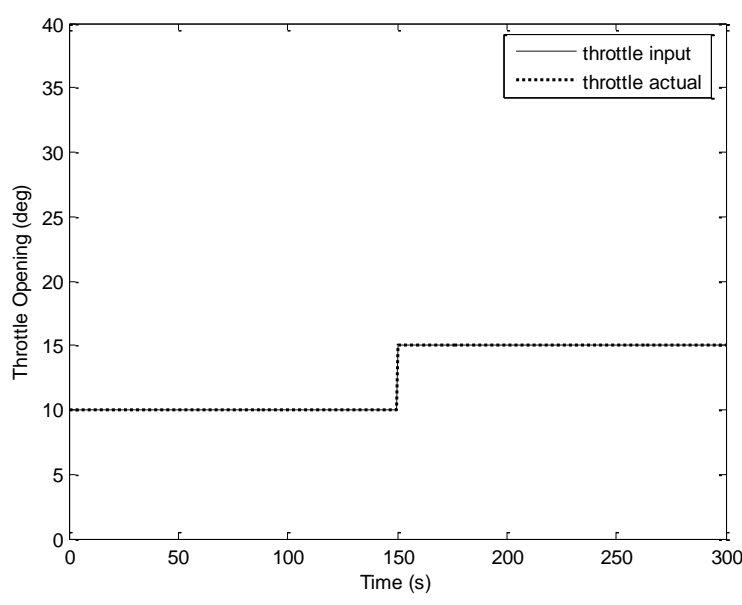

Figure 6. Engine operating without a controller: throttle input (by driver) vs. throttle actual (uncontrolled) 


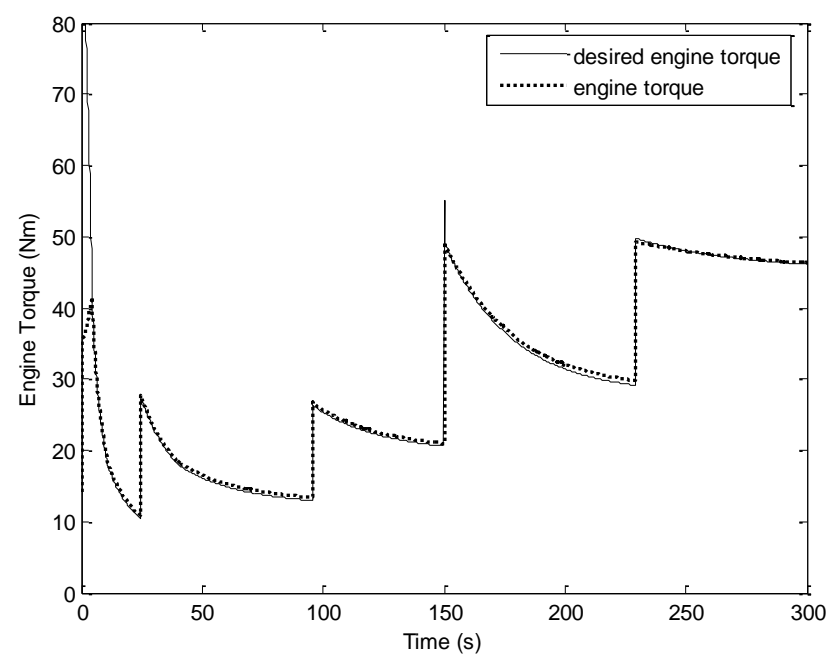

Figure 7. Engine operating with LQIT optimal controller: desired engine torque (reference) vs. engine torque (actual engine torque)

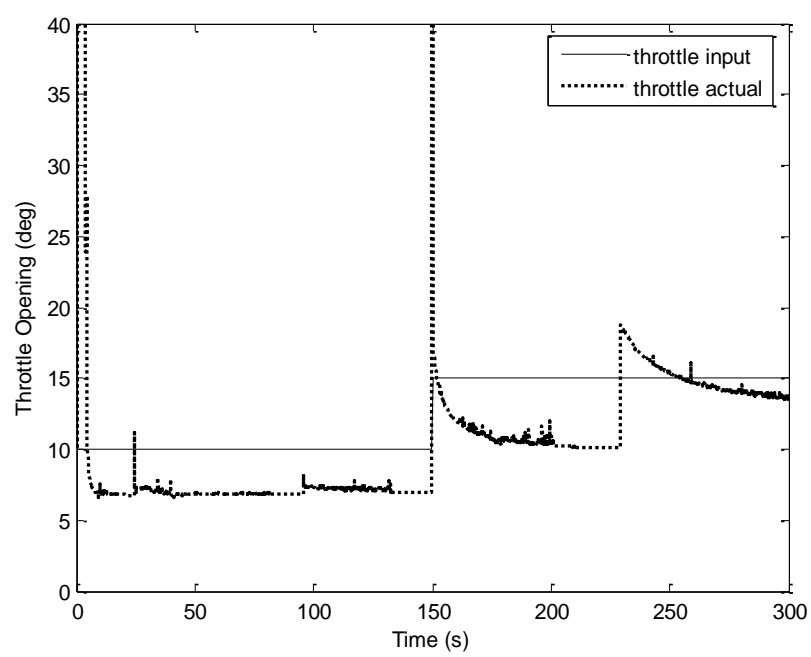

Figure 8. Engine operating with LQIT optimal controller: throttle input (by driver) vs. throttle actual (controlled)

APPENDIX A

MAtlab Simulink Model of Spark IGNition Engine

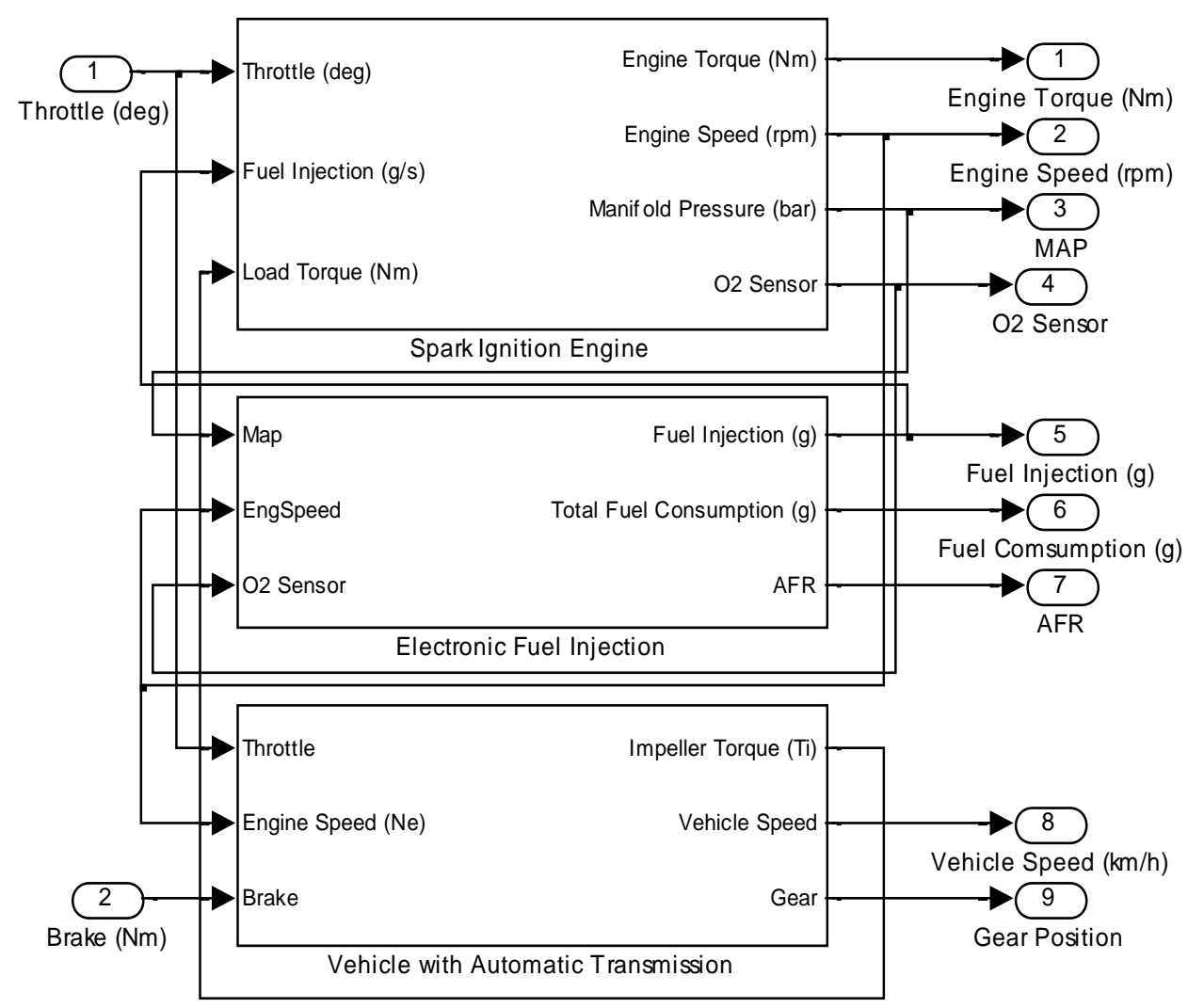

Figure A1. Spark ignition engine model with electronic fuel injetion and automatic transmision 


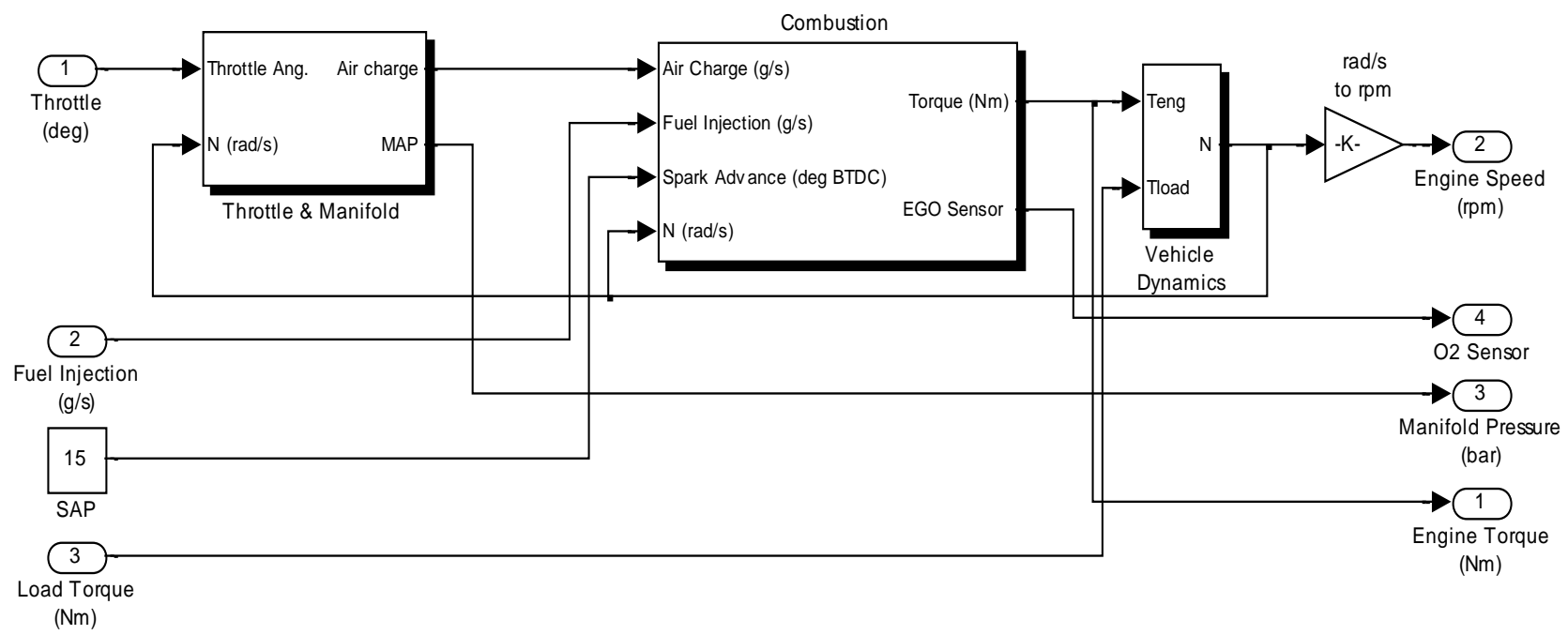

Figure A2. Spark ignition engine model (see [10] for more detail information)

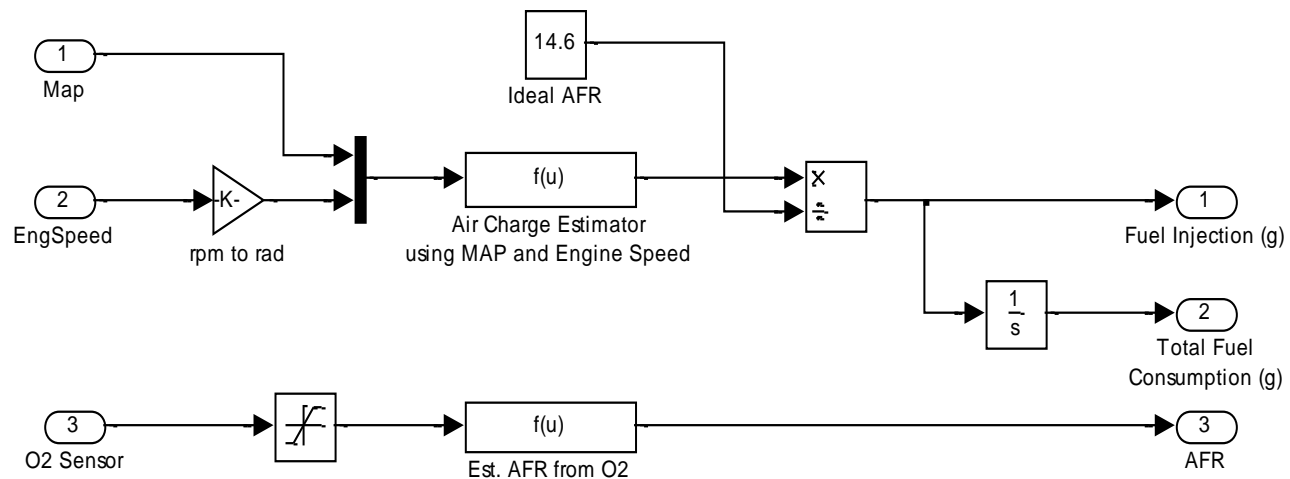

Figure A3. Model of electronic fuel injection

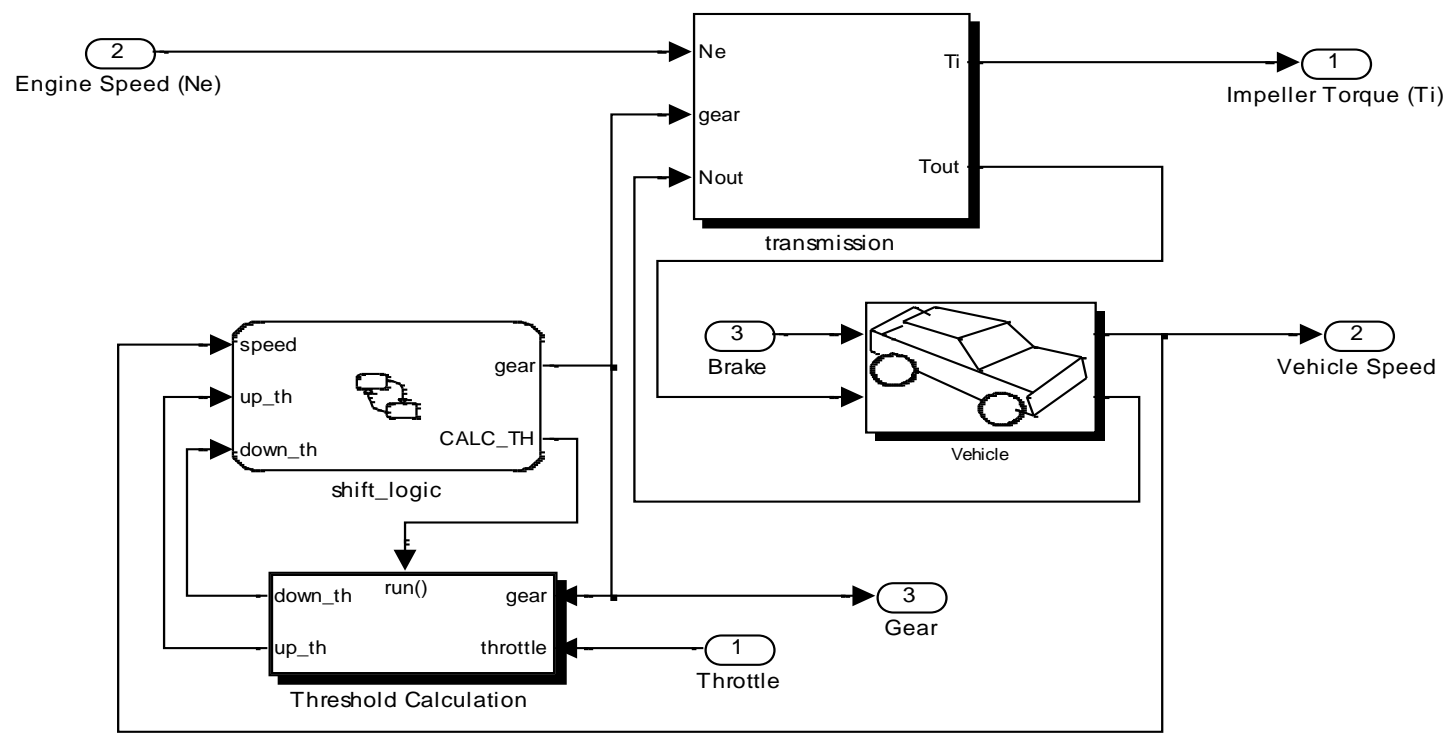

Figure A4. Model of automatic transmission (see [9] for more detail information) 


\section{REFERENCES}

[1] A. Nugroho, "Desain Kompensator Sistem Pengaturan Kecepatan pada Spark Ignition Engine dengan Menggunakan QFT." Bachelor Final Project, Dept. of Electrical Engineering, Faculty of Industrial Technology, ITS, Surabaya, Indonesia, 2004.

[2] A. Salim. "Desain Kompensator sebagai Kontrol Robust pada Sistem Pengapian Spark Ignition Engine,” Master Thesis, Dept. of Electrical Engineering, Faculty of Industrial Technology, ITS, Surabaya, Indonesia, 2004.

[3] Irianto. "Analisis Sistem Pengaturan Kecepatan Spark Ignition Engine Menggunakan Kontrol Robust MIMO," Master Thesis, Dept. of Electrical Engineering, Faculty of Industrial Technology, ITS, Surabaya, Indonesia, 2005.

[4] D. Khiar, J. Lauber, T. Floquet, G. Colin, T.M. Guerra, Y. Chamaillard, "Robust Takagi-Sugeno fuzzy control of a spark ignition engine," Control Eng. Pract. Elsevier, vol.15, no.12,1446, 2007.

[5] T. Nagata and M. Tomizuka, "Robust engine torque control by iterative learning control," presented at American Control Conference, ACC '09, New Jersey, USA, p.2064, 2009.
[6] N. Heintz, M. Mews, G. Stier, and A. Beaumont, "An Approach to Torque-Based Engine Management Systems," SAE Technical Paper 2001-01-0269, doi:10.4271/2001-01-0269, 2001

[7] I. Kolmanovsky, M. Druzhinina, and J. Sun, "Nonlinear Torque and Air-to-Fuel Ratio Controller for Direct Injection Stratified Charge Gasoline Engines," in Proceeding of AVEC, 5th Int'l Symposium on Advanced Vehicle Control, Michigan, p.1.

[8] D. M. Lamberson, "Torque Management of Gasoline Engine," Thesis Master, Mechanical Engineering, University of California at Berkeley, California, 2003.

[9] A. Stefanopoulou, "Modeling and Control of Advanced Technology Engine," Ph.D. Dissertation, Dept. of Electrical Engineering: Systems, University of Michigan, USA, 1996.

[10] The MathWorks Inc.,"Using Simulink and Stateflow in Automotive Applications," The MathWorks Inc., USA, 92, 1998.

[11] M. Athans, "A Tutorial on the LQG/LTR Method," in Proc. American Control Conference, ACC '86, vol.2, 1986, pp. 12891296. 